\title{
Morphology of invasion: body size patterns associated with establishment of Coccinella septempunctata (Coleoptera: Coccinellidae) in western North America
}

\author{
EDWARD W. EVANS \\ Department of Biology, Utah State University, Logan, UT 84322-5305, USA; e-mail: ewevans@biology.usu.edu
}

\begin{abstract}
Key words. Biological control, biological invasions, body size, Coccinella septempunctata, Coccinella tranversoguttata, Coccinellidae, exotic species, Hippodamia convergens, Hippodamia quinquesignata, Hippodamia sinuata, Hippodamia tredecimpunctata, habitat distribution, interspecific competition, intraguild predation, invasive species
\end{abstract}

\begin{abstract}
The Old World ladybird Coccinella septempunctata has rapidly established itself as an abundant, widespread species throughout North America. Overwintering individuals of this species, and of native ladybirds, were collected from early season alfalfa in northern Utah during the period of initial establishment of the invader (1989 to 1999), and were measured for body size. Adult body size can vary widely within insect species, often reflecting differential success of individuals as immatures in obtaining food. Here I examine patterns of ladybird body size to address two questions associated with the establishment of $C$. septempunctata: (1) is there evidence for adverse impact on native species?, and (2) why has the invader has been so successful in establishment? As an indirect test of adverse competitive effect of the invader on native species, I determined whether mean body size of adults of the five most common native species (Coccinella tranversoguttata, Hippodamia convergens, $H$. quinquesignata, $H$. sinuata, and $H$. tredecimpunctata) declined over the period 1991-1997 as the invader increased rapidly in abundance. No such decline was observed for any of these species, thus providing no evidence that the invader's establishment has significantly increased scramble competition for food among immature ladybirds. I also compared body size distribution of the invading species with that of native species. The invader was distinctive in having particularly large variation in body size among individuals (i.e., in having relatively high proportions of both unusually large and small individuals). Such results are consistent with the hypothesis that the invader's success derives from being a generalist with much "ecological flexibility" in regard to the conditions under which it engages and succeeds in reproduction.
\end{abstract}

\section{INTRODUCTION}

Since its discovery in the northeastern U.S. in 1973 (Angalet et al., 1979), the Old World ladybird Coccinella septempunctata L. (Coleoptera: Coccinellidae), a predator principally of aphids (e.g., Hodek, 1973; Gordon, 1985; Hodek \& Honěk, 1996), has spread rapidly to establish itself as a dominant species throughout North America (e.g., Schaefer et al., 1987; Elliot et al., 1996). In light of its rapid rise in abundance, two obvious issues arise concerning the biology of this invader and the native ladybird species with which it now shares North American habitats: (1) has the arrival of C. septempunctata had adverse impact on native ladybird species?, and (2) why has the invader been so successful in establishing in a new continent (does this species exhibit unusual traits that promote its success as an invader?)?

Most attention has centered on the first of these questions (e.g., Obrycki et al., 1987; Schaefer et al., 1987; Elliott \& Kieckhefer, 1990; Kieckhefer \& Elliott, 1990; Ruesink et al., 1995; Simberloff \& Stiling, 1996; Obrycki et al., 2000; but see also Phoofolo \& Obrycki, 1995; Evans et al., 1999). Elliott et al. (1996) analyzed longterm data to detect numerical decreases in native species (C. transversoguttata richardsoni Brown and Adalia bipunctata [L.]) in agricultural crops of central North America. In general, however, it has proved difficult to quantify ladybird numbers sufficiently well to test for population declines over large geographic areas, as these mobile predators disperse continually and widely among habitats in search of ephemeral populations of their aphid prey (e.g., Duelli et al., 1990; Maredia et al., 1992; Ives et al., 1993; Colunga-Garcia et al., 1997; Evans \& Richards, 1997). Nevertheless, more anecdotal sources of evidence also suggest that populations of native North American ladybirds may be declining as a result of the rise in numbers of C. septempunctata (Staines et al., 1990; Wheeler \& Hoebeke, 1995; Simberloff \& Stiling, 1996; Ellis et al., 1999). The simplest hypothesis to account for such declines is that native species have suffered from increased scramble competition for food (e.g., Evans, 1991; Elliott et al., 1996; see also Niemela \& Mattson, 1996), although an alternative possibility is that these species have been victimized by $C$. septempunctata through intraguild predation (Hironori \& Katsuhiro, 1997; Obrycki et al., 1998; see also Agarwala \& Dixon, 1992).

Here I present another line of inquiry to probe whether the arrival of $C$. septempunctata has adversely affected native ladybirds through increased scramble competition for food (the "competition hypothesis"). I focus in particular on the body size of individual adult ladybirds. Adult body size can vary widely in many insect species, in most cases likely as the result both of underlying genetic variation (e.g., Dingle, 1984; see also Fox et al., 1999), and of the environmental conditions experienced during growth of the immature stages (e.g., Gullan \& 
Cranston, 1994; Hodek \& Honěk, 1996). For predatory insects in general (e.g., Evans, 1982; Juliano 1985; Ernsting et al., 1992; Legaspi \& O’Neil, 1994; Van Dijk, 1994) and for ladybirds in particular (e.g., Blackman, 1965; Honěk, 1983; Obrycki \& Orr, 1990; Orr \& Obrycki, 1990), the quality and quantity of the food supply for immature stages can have significant impact on the size achieved by the adult insect.

Given that adult body size can reflect larval food supply, I test the competition hypothesis here by assessing whether adults of native aphidophagous ladybirds in northern Utah have declined in average body size following the arrival of $C$. septempunctata. I also compare variability in body size between $C$. septempunctata and native ladybird species to explore whether $C$. septempunctata is distinctive such as to suggest the general ecological basis for its striking success in establishing itself across North America. Greater variability on the part of the invader would be consistent with the hypothesis that C. septempunctata is more generalized than are native species in the environmental conditions under which it succeeds in developing (more generally, successful invaders are often hypothesized to be "generalists"; e.g., see reviews by Lodge, 1993a,b). Conversely, less variability on the part of the invader would be provocative in that it might reflect that the invader's success lies particularly in its superior ability to capitalize on a narrow range of favorable conditions under which to develop (e.g., see Evans, 1982).

\section{MATERIAL AND METHODS}

Representative samples of adult ladybirds were collected from alfalfa in the spring in northern Utah (Cache Valley). These ladybirds had developed to adulthood the previous year in unknown but presumably diverse habitats and environmental conditions (including quantity and quality of food supply). Upon emergence from overwintering sites, they dispersed into alfalfa fields (and other habitats) to feed on aphids and other prey and to reproduce (e.g., see Evans \& Youssef, 1992). Thus, the analyses presented concern ladybird metapopulations over the landscape, rather than just populations of beetles developing in alfalfa.

In the springs of 1989 and 1991-1999, ladybirds were sampled by sweep net and/or hand collection (with all species collected as encountered) from alfalfa fields near Logan, Utah. Eight fields were sampled in 1989 in both early and late May (see Evans \& Youssef, 1992), seventeen fields were sampled during May 1992, and one field only was sampled (on four occasions) during the unusually cold and wet spring of 1995 . In other years, two or three fields were sampled repeatedly (generally at weekly intervals) throughout the period late April-early June.

Ladybirds were frozen upon collection, and sorted and identified to species and sex at a later occasion. Specimens collected in 1991-1997 were also measured for body size with aid of a micrometer at $7.5 \mathrm{x}$ under a dissecting microscope. Three measurements were made on each individual: maximum width of the abdomen and maximum width of the pronotum (both as viewed ventrally), and length of the elytron (as viewed dorsally along the inner edge). Because all three measurements were highly correlated with each other for individuals of each sex in all spe- cies, only the width of the abdomen is presented below as an index of overall body size of an individual female or male.

In addition to the invader $C$. septempunctata, five species of native North American ladybirds (C. transversoguttata, Hippodamia sinuata crotchi Casey; H. convergens Guerin, H. quinquesignata quinquesignata [Kirby], and H. tredecimpunctata tibialis [Say]) were collected in sufficient numbers each year (1991-1997) to test whether a long-term decline in average body size of these species occurred as the invader became more numerous, and to compare the variability in body size of the introduced versus native species (as reflected by the coefficient of variation in body size; i.e., the standard deviation divided by the mean, expressed as a percentage; Sokal \& Rohlf, 1981). Patterns of body size based on spring-collected individuals (that became adults the previous year) might be influenced by differential survivorship of individuals of varying size over the winter; Honěk (1997), however, concluded that winter survival was not significantly affected by body size in European populations of $C$. septempunctata.

\section{RESULTS AND DISCUSSION}

No individuals of $C$. septempunctata were recovered from alfalfa fields in northern Utah in 1989, but the invader had appeared in low numbers by 1991 and thereafter rose rapidly in abundance such that by $1999,95 \%$ of adult ladybirds collected from alfalfa during the first crop were individuals of this species (Fig. 1). As dramatic as this change is, it alone cannot be taken as evidence of adverse effect of the invader on native ladybirds. Because absolute numbers of ladybirds in alfalfa vary so greatly among fields and years (depending in part upon local abundance of aphids; e.g., Honěk, 1982; Evans and Youssef, 1992; Ives et al., 1993), it is difficult to determine if the changing relative abundance of the invader in alfalfa fields resulted primarily from an increase in its own numbers or also from a general decline in numbers of native species.

During the period of rapid build-up in numbers of the invader, the average body size of the five most abundant native ladybird species in alfalfa showed no tendency to decline (Fig. 2; for neither males or females of any of the five species was there a significant negative correlation

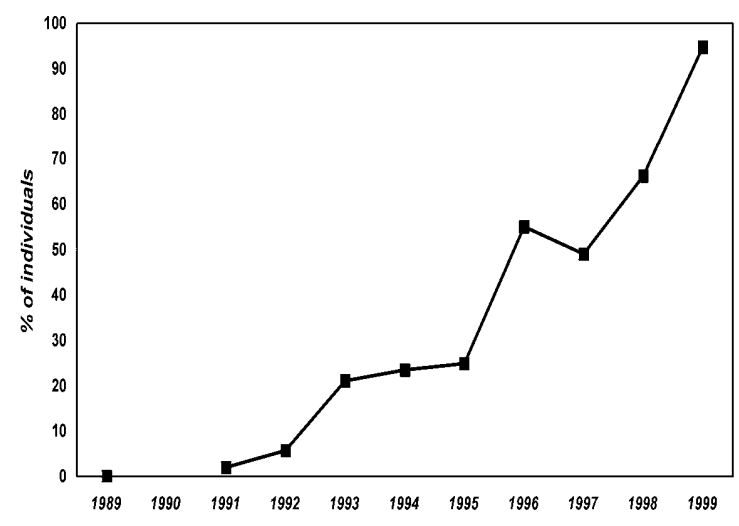

Fig. 1. Percentage of ladybird adults (all species combined) collected in alfalfa fields in northern Utah during the springs of 1989-1999 that belonged to the invasive species, C. septempunctata. 

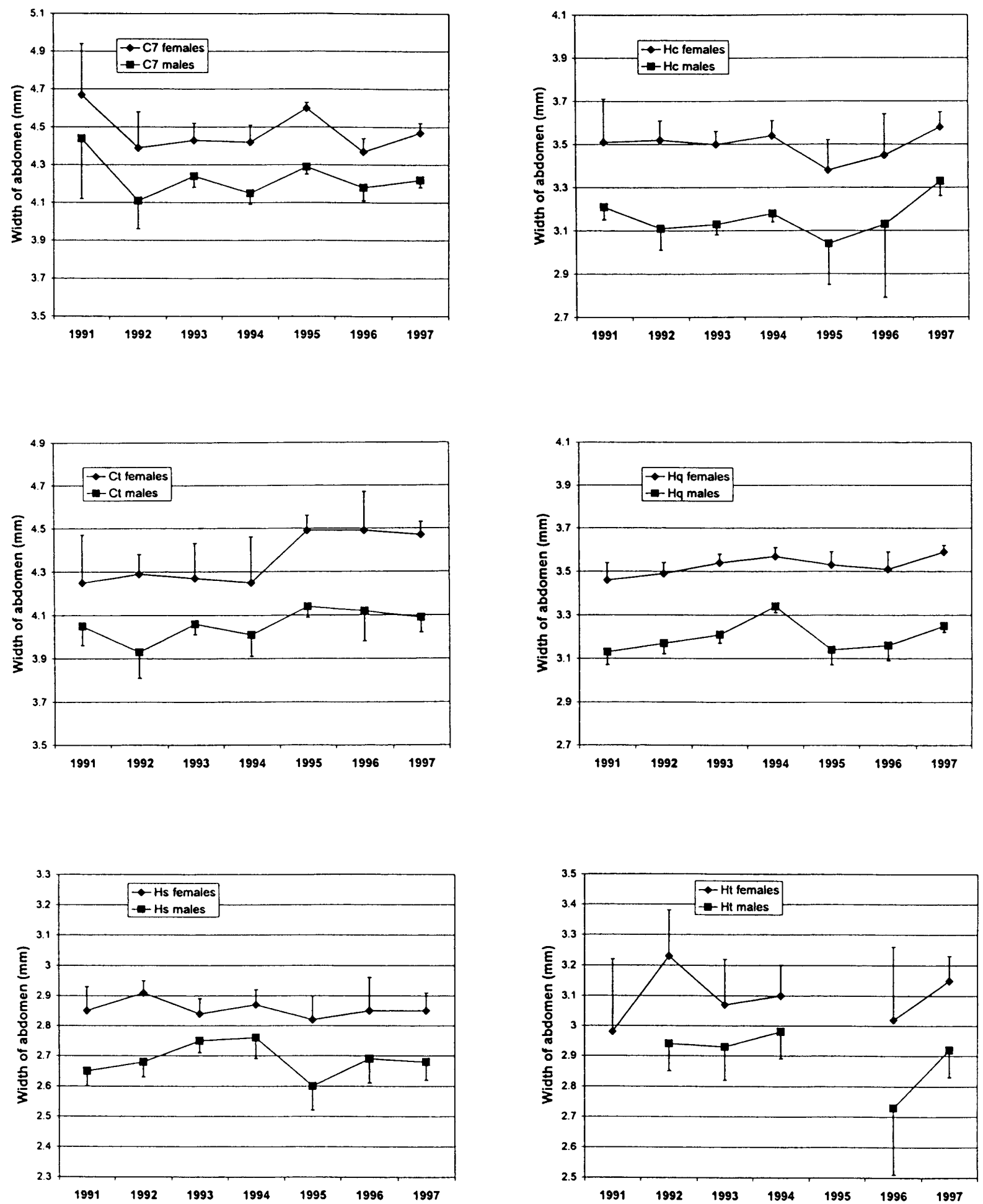

Fig. 2. Widths of abdomens (means $+/-2$ s.e.) of adult ladybirds collected in alfalfa in northern Utah during the springs of 1991-1997 for females (top line in each panel) and males (bottom line in each panel) of (left, top to bottom): C. septempunctata (C7), C. transversoguttata (Ct), Hippodamia sinuata (Hs); and (right, top to bottom): H. convergens (Hc), H. quinquesignata (Hq), and H. tredecimpunctata $(\mathrm{Ht})$.

between abdominal width and year of collection $[p \geq 0.10$ in all cases both for mean width per year, and for individual widths each year]). Indeed, the only marked trend in body size suggested by the data is an intriguing possibility of increase rather than the predicted decrease for $C$. transversoguttata (particularly females). During this same period of years, the mean body size of C. septempunctata neither consistently increased nor decreased as the invader became more firmly established (Fig. $2 ; p>0.45$ for correlations of size and year for both mean and individual widths of males and females). 

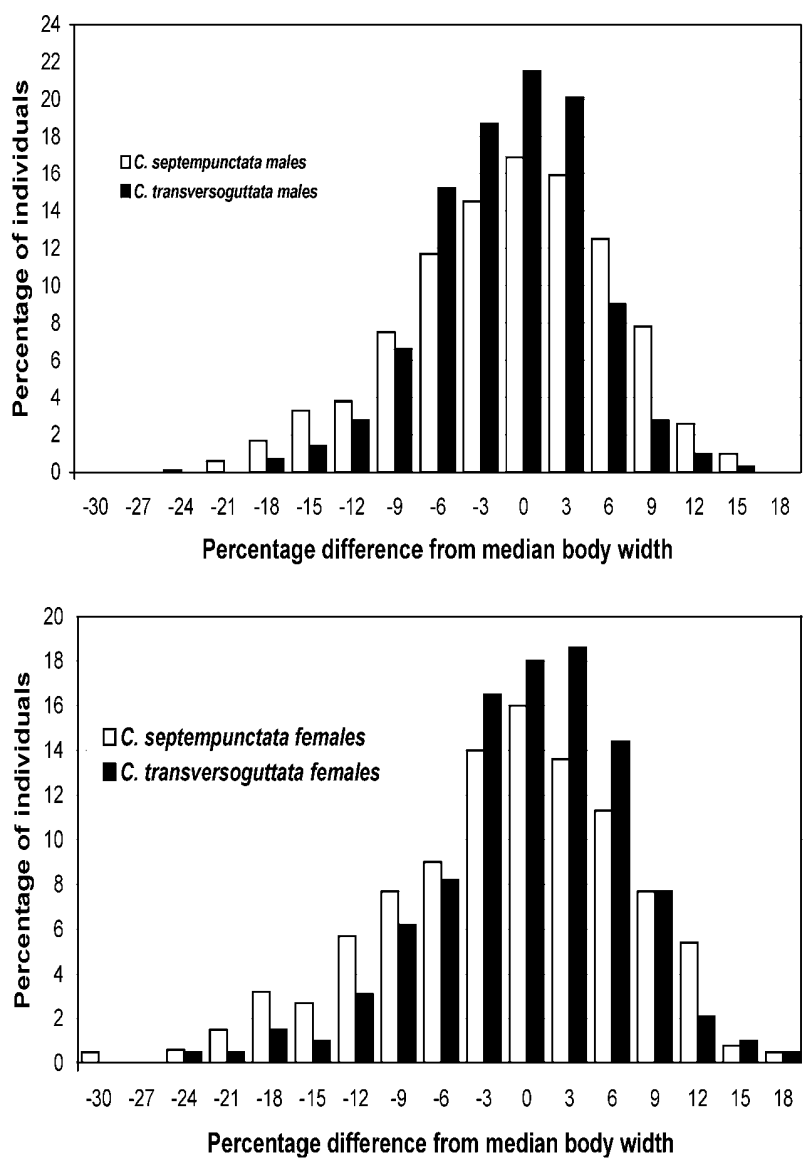

Fig. 3. Percentage of individuals of $C$. septempunctata and $C$. transversoguttata collected in alfalfa fields in northern Utah during the springs of 1991-1997 that deviated in width by a given percentage from the median width of the population. Top: adult males (total number of individuals collected, $\mathrm{N}=811$ and 289 , and median width $=4.27$ and $4.13 \mathrm{~mm}$, for $C$. septempunctata and $C$. transversoguttata, respectively). Bottom: adult females $(\mathrm{N}=664$ and 194 , and median width $=4.53$ and 4.40 $\mathrm{mm}$, for C. septempunctata and C. transversoguttata, respectively).

These body size data hence fail to provide any clear support for the hypothesis that increased scramble competition for food stemming from the arrival of C. septempunctata has adversely affected native North American ladybirds. The absence of clear declines in body size of native species over time, on the other hand, is not at odds with the leading alternative to this competition hypothesis, the intraguild predation hypothesis wherein adverse effects result primarily from the invader preying upon eggs and larvae of native species (e.g., Hironori \& Katsuhiro, 1997; Obrycki et al., 1998). Another possibility (the "habitat compression hypothesis") is that at least in northern Utah, the arrival of C. septempunctata has resulted primarily in habitat redistribution or compression (perhaps with consequent reduction in overall numbers) of native species. Thus, although numbers of native ladybirds may have declined in alfalfa as numbers of the invader have increased, this may simply reflect that C. septempunctata thrives in alfalfa (as it does generally in field crops of Europe; e.g., Honěk \& Rejmánek, 1982;
Honěk, 1985) and thereby so reduces prey populations as to make this habitat no longer attractive to native species. Hence, with the arrival of the invader, the native species may have "retreated" from the non-native alfalfa ecosystem (with which they have only come to be associated over the last one hundred and thirty years) to other habitats (e.g., "ancestral habitats") where they still find sufficient prey as larvae to maintain as a metapopulation an unchanging average body size. Indeed, my collections and observations in native habitats of northern Utah during the 1990s indicate that although C. septempunctata is broadly distributed across the landscape, it has not become (at least yet) as dominant a member of the local ladybird fauna in these environments as it is in alfalfa. For example, the invader represented only 3\% (3 of 93 individuals) of adult ladybirds (of several species of $\mathrm{Coc}$ cinella and Hippodamia) collected on native riparian vegetation and adjacent sagebrush (Artemisia tridentata Nutt., Asteraceae) in May 1999 (see Youssef \& Evans, 1994 for further description of the sampling site).

Can we probe the patterns of adult body size to address why $C$. septempunctata has been so successful in establishing itself in North America? In this light, it is provocative to compare intraspecific variation in adult body size among ladybird species. For example, the median sizes of individuals of a given sex of $C$. septempunctata and C. transversoguttata collected in 1991-1997 are nearly identical, but the variation in body size is less tightly constrained around the median for the invader than for the native (Fig. 3; Likelihood ratio chi-square tests with tails of the distribution $[12 \%$ or more deviation from the median] collapsed into single categories: $\mathrm{G}^{2}$ for males $=31.59$, d.f. $=8, p<0.001 ; \mathrm{G}^{2}$ for females $=15.45$, d.f. $=8, p=0.051$ ). When one compares variation in body size of the invader with that of native ladybirds in general, the coefficient of variation (combined data, 1991-1997) of C. septempunctata is significantly greater than those of native species (Fig. 4; t test comparisons of a single observation with the mean of a sample [Sokal \& Rohlf, 1981]: $\mathrm{t}_{\mathrm{s}}=4.592, p<0.02$ for females, and $\mathrm{t}_{\mathrm{s}}=$ $3.058, p<0.05$ for males).

Adult body size in ladybirds is likely the outcome of a complex interaction of genotype with environmental conditions experienced by the developing immature predator. To the extent that genetic variation is important, one might expect a founder effect to result in the invader displaying relatively low variability in body size. Krafsur et al. (1992), however, found no evidence for reduction in genetic diversity associated with colonization of North America by C. septempunctata (see also Meffert, 1999). On the other hand, the high variability in body size observed for C. septempunctata may reflect that this species possesses unusually high genetic variation for body size such that individuals collectively can succeed in developing under unusually diverse conditions (e.g., individuals with genetic propensity for small adult size may be able to develop successfully even when prey densities are unusually low). Such a possibility is difficult to distinguish, of course, from the possibility that females readily 


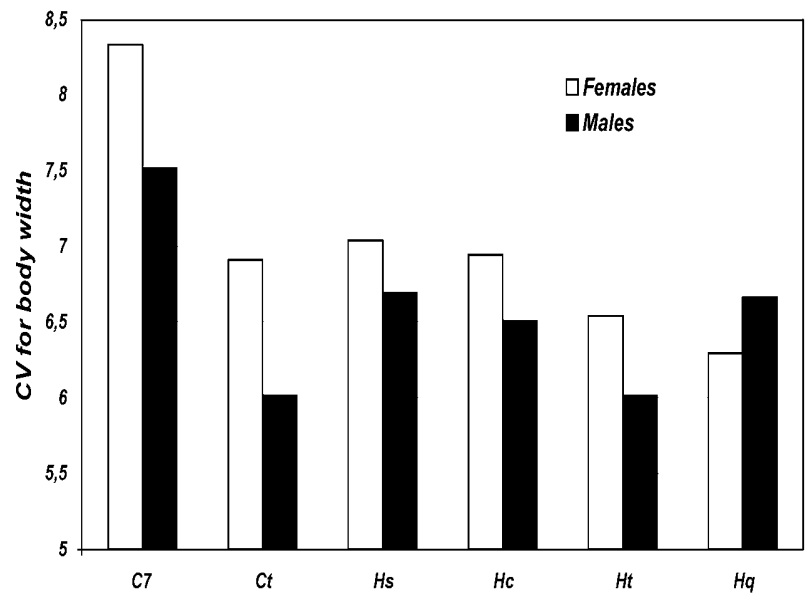

Fig. 4. Coefficient of variation $(\mathrm{CV}=$ standard deviation/ mean $\times 100$; Sokal \& Rohlf, 1981) for adult ladybirds collected in alfalfa in northern Utah during the springs of 1991-1997 for C. septempunctata $(\mathrm{C} 7 ; \mathrm{N}=664$ females and 811 males), C. transversoguttata $(\mathrm{Ct} ; \mathrm{N}=194$ females and 289 males), $H$. sinuata (Hs; $\mathrm{N}=330$ females and 254 males), $H$. convergens (Hc; $\mathrm{N}=196$ females and 208 males), H. tredecimpunctata $(\mathrm{Ht}$; $\mathrm{N}=61$ females and 48 males), and $H$. quinquesignata $(\mathrm{Hq} ;$ $\mathrm{N}=722$ females and 254 males).

reproduce under diverse conditions with the result that their offspring achieve highly variable adult sizes (even in the absence of significant genetic variation for body size) depending on their varying larval experiences, particularly as regards food quality and quantity (e.g., see Honěk, 1983). Hodek \& Honěk (1996) characterize C. septempunctata as an r-selected species that engages in high-risk overproduction of progeny that often results in a great proportion of offspring failing to survive. In this behavior, C. septempunctata may be distinctive in comparison with North American species in being a generalist with a high degree of "ecological flexibility" that attempts and is able to reproduce successfully under many conditions. The flexibility particularly associated with its reproductive habits may be a critical factor contributing to the very rapid rise in abundance of this successful invader throughout the North American continent.

ACKNOWLEDGEMENTS. I thank R. Aycock, K. Bailey, T. Clark, S. England, H. Hammond, M. Harrison, A. Kalaskar, C. Keyes, A. Mull, A. Nelson, S. Jeffries, D. Richards, T. Tammela, A. Stevenson, N. Tolley, \& N. Youssef for assistance in collecting and measuring ladybirds; J. Obrycki, T. Kring, \& R. Karban for discussion; A. Honěk and an anonymous reviewer for comments on the manuscript; and the NSF, USDA (NRI), and Utah Agricultural Experiment Station for financial support.

\section{REFERENCES}

Agarwala B.K. \& Dixon A.F.G. 1992: Laboratory study of cannibalism and interspecific predation in ladybirds. Ecol. Entomol. 17: 303-309.

Angalet G.W., Tropp J.M. \& Eggert A.N. 1979: Coccinella septempunctata in the United States: recolonizations and notes on its ecology. Envir. Entomol. 8: 896-901.
Blackman R.L. 1965: Studies on specificity in Coccinellidae. Ann. Appl. Biol. 56: 336-338.

Colunga-Garcia M., Gage S.H. \& Landis D.J. 1997: Response of an assemblage of Coccinellidae (Coleoptera) to a diverse agricultural landscape. Envir. Entomol. 26: 797-804.

Dingle H. 1984: Behavior, genes, and life histories: complex adaptations in uncertain environments. In Price P.W., Slobodchikoff C.N. \& Gaud W.S. (eds): A New Ecology: Novel Approaches to Interactive Systems. John Wiley \& Sons, Inc., New York, pp. 169-194.

Duelli P., Studer M., Marchand I. \& Jakob S. 1990: Population movements of arthropods between natural and cultivated areas. Biol. Conserv. 54: 193-207.

Elliott N.C. \& KiecKhefer R.W. 1990: Dynamics of aphidophagous coccinellid assemblages in small grain fields in eastern South Dakota. Envir. Entomol. 19: 1320-1329.

Elliott N.C., KieckHefer R. \& Kauffman W. 1996: Effects of an invading coccinellid on native coccinellids in an agricultural landscape. Oecologia 105: 537-544.

Ellis D.R., Prokrym D.R. \& Adams R.G. 1999: Exotic lady beetle survey in northeastern United States: Hippodamia variegata and Propylea quatuordecimpunctata (Coleoptera: Coccinellideae). Entomol. News 110: 73-84.

Ernsting G., Isaaks J.A. \& Berg M.P. 1992: Life cycle and food availability indices in Notiophilulus biguttatus (Coleoptera: Carabidae). Ecol. Entomol. 17: 33-42.

Evans E.W. 1982: Timing of reproduction by predatory stink bugs (Hemiptera: Pentatomidae): patterns and consequences for a generalist and a specialist. Ecology 63: 147-158.

Evans E.W. 1991: Intra versus interspecific interactions of ladybeetles (Coleoptera: Coccinellidae) attacking aphids. Oecologia 87: 401-408.

Evans E.W. \& Youssef N.N. 1992: Numerical responses of aphid predators to varying prey density among Utah alfalfa fields. J.Kans. Entomol. Soc. 65: 30-38

Evans E.W. \& Richards D.R. 1997: Managing the dispersal of ladybird beetles (Col.: Coccinellidae): use of artificial honeydew to manipulate spatial distributions. Entomophaga 42: 93-102.

Evans E.W., Stevenson A.T. \& Richards D.R. 1999: Essential versus alternative foods of insect predators: benefits of a mixed diet. Oecologia 121: 107-112.

Fox C.W., Czesak M.E., Mousseau T.A. \& Roff D.A. 1999: The evolutionary genetics of an adaptive maternal effect: egg size plasticity in a seed beetle. Evolution 53: 552-560.

Gordon R.D. 1985: The Coccinellidae (Coleoptera) of America north of Mexico. J. N.Y. Entomol. Soc. 93: 1-912.

Gullan P.J. \& Cranston P.S. 1994: The Insects. An Outline of Entomology. Chapman and Hall, New York, 491 pp.

HiRonori Y. \& KATSUHiRo S. 1997: Cannibalism and interspecific predation in two predatory ladybirds in relation to prey abundance in the field. Entomophaga 42: 153-163.

Hodek I. 1973: Biology of Coccinellidae. Academia, Prague \& Dr W. Junk, The Hague, 260 pp.

Hodek I. \& HonĚK A. 1996: Ecology of Coccinellidae. Kluwer Academic Publishers, Dordrecht, The Netherlands, 464 pp.

HoNĚK A. 1982: Factors which determine the composition of field communities of adult aphidophagous Coccinellidae (Coleoptera). Z. Angew. Entomol. 94: 157-168.

HoNĚK A. 1983: Factors affecting the distribution of larvae of aphid predators (Col., Coccinellidae and Dipt., Syrphidae) in cereal stands. Z. Angew. Entomol. 95: 336-345.

HoNĚK A. 1985: Habitat preferences of aphidophagous coccinellids (Coleoptera). Entomophaga 30: 253-264. 
HONĚK A. 1997: Factors determining winter survival in Coccinella septempunctata (Col.: Coccinellidae). Entomophaga $\mathbf{4 2}$ 119-124.

HonĚK A. \& ReJMÁNeK M. 1982: The communities of adult aphidophagous Coccinellidae (Coleoptera): a multivariate analysis. Acta Oecol. Appl. 3: 95-104.

Ives A.R., Kareiva P. \& Perry R. 1993: Response of a predator to variation in prey density at three hierarchichal scales: lady beetles feeding on aphids. Ecology 74: 1929-1938.

Julrano S.A. 1985: The effects of body size on mating and reproduction in Brachinus lateralis (Coleoptera: Carabidae). Ecol. Entomol. 10: 271-280.

KieCKHEFer R.W. \& Elliott N.C. 1990: A 13-year survey of the aphidophagous Coccinellidae in maize fields in eastern South Dakota. Can. Entomol. 122: 579-581.

Krafsur E.S., Obrycki J.J. \& Flanders R.V. 1992: Gene flow in populations of the seven-spotted lady beetle, Coccinella septempunctata. $J$. Heredity 83: 440-444.

LEGASPI J.C. \& O'NEIL R.J. 1994: Developmental response of nymphs of Podisus maculiventris (Heteroptera: Pentatomidae) reared with low numbers of prey. Envir. Entomol. 23: 374-380.

LODGE D.M. 1993a: Species invasions and deletions: community effects and responses to climate and habitat change. In Kareiva P.M., Kingsolver J.G. \& Huey R.B. (eds): Biotic Interactions and Global Change. Sinauer Associates Inc., Sunderland, MA, pp. 367-387.

LODGE D.M. 1993b. Biological invasions: lessons for ecology. Trends Ecol. Evolut. 8: 133-137.

Maredia K.M., Gage S.H., Landis D.A. \& SCriber J.M. 1992 Habitat use patterns by the seven-spotted lady beetle (Coleoptera: Coccinellidae) in a diverse agricultural landscape. Biological Control 2: 159-165.

MefFeRT L.M. 1999: How speciation experiments relate to conservation biology. BioScience 49: 701-711.

Niemela P. \& MATTSON W.J. 1996: Invasion of North American forests by European phytophagous insects. BioScience 46 : $741-753$

Obrycki J.J., Bailey W.C., Stoltenow C.R., Puttler B. \& CARLSON C.E. 1987: Recovery of the seven-spotted lady beetle, Coccinella septempunctata (Coleoptera: Coccinellidae), in Iowa and Missouri. J. Kans. Entomol. Soc. 60: 584-588.

OBRYCKI J.J. \& ORR C.J. 1990: Suitability of three prey species for nearctic populations of Coccinella septempunctata, Hippodamia variegata, and Propylea quatuordecimpunctata (Coleoptera: Coccinellidae). J. Econ. Entomol. 83: 1292-1297
Obrycki J.J., Giles K.L. \& Ormord A.M. 1998: Interactions between an introduced and indigenous coccinellid species at different prey densities. Oecologia 117: 279-285.

Obrycki J.J., Elliott N.C. \& Glles K.L. 2000: Coccinellid introductions: potential for and evaluation of non-target effects. In Follett P.A. \& Duan J.J. (eds): Nontarget Effects of Biological Control. Kluwer Acad. Publ., Boston, MA, pp. 127-145.

ORR C.J. \& OBRYCKI J.J. 1990: Thermal and dietary requirements for development of Hippodamia parenthesis (Coleoptera: Coccinellidae). Envir. Entomol. 19: 1523-1527.

Phoofolo M. \& Obrycki J.J. 1995: Comparative life-history studies of nearctic and palearctic populations of Coccinella septempunctata (Coleoptera: Coccinellidae). Envir. Entomol. 24: $581-587$.

Ruesink J.L., Parker I.M., Groom M.J. \& Kareiva P.M. 1995: Reducing the risks of nonindigenous species introductions. BioScience 45: 465-477.

Schaefer P.W., Dysart R.J. \& Specht H.B. 1987: North American distribution of Coccinella septempunctata (Coleoptera: Coccinellidae) and its mass appearance in coastal Delaware. Envir. Entomol. 16: 368-373.

Simberloff D. \& Stiling P. 1996: How risky is biological control? Ecology 77: 1965-1974.

SOKal R.R. \& RoHlf F.J. 1981: Biometry. Second Edition. W.H. Freeman and Co., San Francisco, CA. 859 pp.

Staines C.L. JR., RothChild M.J. \& Trumble R.B. 1990: A survey of the Coccinellidae (Coleoptera) associated with nursery stock in Maryland. Proc. Entomol. Soc. Wash. 92: 310-313.

VAN DIJK T.S. 1994: On the relationship between food, reproduction and survival of two carabid beetles: Calathus melanocephalus and Pterostichus versicolor. Ecol. Entomol. 19. 263-270.

WheELER A.G. \& HoEbeKe E.R. 1995: Coccinella novemnotata in northeastern North America: historical occurrence and current status (Coleoptera: Coccinellidae). Proc. Entomol. Soc. Wash. 97: 701-716.

Youssef N.N. \& Evans E.W. 1994: Exploitation of Canada Thistle by the weevil Rhinocyllus conicus (Coleoptera: Curculionidae) in northern Utah. Envir. Entomol. 23: 1013-1019.

Received January 6, 2000; accepted May 23, 2000 